\title{
Management of Academic Advising in Higher Educational Institutions during COVID-19 Pandemic
}

\author{
Rabab Ali Abumalloh ${ }^{a^{*}}$, Azzah Ibrahim Alghamdi ${ }^{\mathrm{b}}$, Nedaa Azzam ${ }^{\mathrm{c}}$ and Abeer Rafi’i Al Abdulra- \\ heem $^{\text {a }}$
}

${ }^{a}$ Computer Department, Community College, Imam Abdulrahman Bin Faisal University, P.O. Box. 1982, Dammam, Saudi Arabia

${ }^{b}$ Department of Biology, College of Science, Imam Abdulrahman Bin Faisal University, P.O. Box 1982-31441, Dammam, Saudi Arabia

cPreparation year, Humanity Track, Imam Abdulrahman Bin Faisal University, P.O. Box 1982-31441, Dammam, Saudi Arabia

\section{H R O N I C L E}

\section{Article history:}

Received: August 10, 2020

Received in revised format:

November 152020

Accepted: November 27, 2020

Available online:

December 4, 2020

Keywords:

Academic advising

$K$-mean clustering

Segmentation

Online services

COVID-19

\section{A B S T R A C T}

COVID -19 pandemic has a huge global impact on education over the world. Many countries decided to close universities, colleges, and schools to limit the spread of this disease. Almost $91 \%$ of students worldwide have shifted to online education. Educational institutions have struggled to provide their students with suitable online learning and assessment tools. As a new experience for both teachers and students, Imam Abdulrahman Bin Faisal University has set new online academic services to make it possible and easy for students to get the help they need and to overcome the new obstacles they are facing. The purpose of this study is to gain a deeper understanding of student satisfaction with their academic advising in light of the new emerging situation. Additionally, directions were presented for the academic advising section members to allow them to manage the unit appropriately. To achieve that, students were clustered regarding their level of satisfaction with the provided services. Students' answers were collected through an online questionnaire and the data were analyzed and segmented using the k-mean clustering technique. Regarding results, recommendations for improvements were suggested and action plans were prepared.

(C) 2021 by the authors; licensee Growing Science, Canada

\section{Introduction}

Higher education facilities provide students with the required knowledge in several fields and play an important role in the process of comprehensive development over several aspects of a person's life. Most students enroll with little or no knowledge about the major they have chosen as a practical track for their future careers. Some might face some difficulties chime with their peers or their instructors. These are some of the reasons most, if not all, educational facilities provide academic advising, whether as a strategy or documented procedures or even as a scheme within the institution. This advising has provided students with great help and support throughout their years of degree pursue (Al-Ansari, El Tantawi, AbdelSalam, \& Al-Harbi, 2015; Gaines, 2014; Lawton, 2018; Powers, Carlstrom, \& Hughey, 2014). According to Iatrellis, Kameas, \& Fitsilis (2017), academic advising can be defined as a systematic or dedicated program in higher education facilities or community colleges to provide guidance and advice to undergraduate students regarding their major and courses. The concept of Academic advising has evolved over the years by many researchers, some stated that it embodies various activities along a prescriptive developmental continuum (Hatch \& Garcia, 2017). This prescriptive development that is achieved through advising can be described to be informational, directive, and unidirectional. While others see it from a wider perspective; as an international interaction between higher education institutions' workers (named advisors), and enrolled students (advisees), in addition to the procedure

\footnotetext{
* Corresponding author.

E-mail address: ramolloh@iau.edu.sa (R. A. Abumalloh) 
through which these advisors follow to provide guidance and support to those advisees in several aspects like personality development, courses and academic path, career choices, and ambition (He \& Hutson, 2016).

Most researchers agree on the importance of academic advising on the wellbeing of students' morals and their will to pursue in the course of study they have chosen (Diederiks \& Figueroa, 2016; Jaradat \& Mustafa, 2017). These benefits come with great advantages on all participants of the educational process: students, instructors (advisors and non-advisors), administrative workers, and the learning process itself. Other benefits highlight the importance of academic advising. To list some:

1. It helps in introducing students to their responsibilities as well as fostering and supporting fruitful engagement, success and retention possibilities (Chan et al., 2019).

2. Some students, who usually come from schools where their timetable is pre-set, feel overwhelmed to schedule their courses and arrange their courses over their first semesters at the university. Academic advising helps in making them feel more relaxed and make suitable choices (Chan et al., 2019).

3. Academic advising is not confined to courses and university study, as advisors can provide students with career choices advice, by introducing different specialties and career duties and positions one can possess, in addition to expected responsibilities, mainly in, but not limited to, healthcare studies (Zarges, Adams, Higgins, \& Muhovich, 2018).

4. Researchers have found a close relationship between academic advising and students' success in their careers. Since advising has a great role in fostering students, and providing them with persistence towards pursuing their career choices (Hatch \& Garcia, 2017).

As the number of students who enroll in higher education institutions increases, and the expertise of academics also grows, the methods and techniques through which academic advising is provided has also developed, especially with the new technologies and procedures that are becoming widely adopted by these institutions. The oldest, and maybe most effective, channels are the face-to-face approach, where a student visits the advisors and have personal interaction and communication (Chan et al., 2019). This approach is not beneficial in providing advice, but it is also helpful in strengthening bonds between academics and students off-class rooms. Researchers have stated that this approach is preferred by some students, while a majority of them preferred other channels. Researchers studied the effectiveness of advising through phone calls (Chan, 2016). This approach was helpful for students who have difficulties attending the university's campus, but still need to have advised on time. This method wasn't very preferred, since other channels could have the same outcomes, while being easier to use. Online advising, through the use of an online portal or a certain website's facility, or e-mails were also investigated by different researchers, like Gaines (2014), who found that electronic channel is most convenient to both students and advisors, and save time and effort in seeking academic advice, in and out university campus; although there's still a big preference to the old fashion direct interaction (the face-to-face advising). With the widespread of social media applications, and the easy access and availability of them with almost everyone, academic advising has found its way into the recruitment of this technology as a dependable channel. Students have shown great acceptance to this approach and felt comfortable with using them to seek academic advice. Yet; for documentation and formalizing university's procedures and academics activities, this approach is not officially acceptable, as an official academic advising channel, although many educational institutions have adopted this approach through official social media applications -like Facebook- through which students can submit their inquiry and a specialist is assigned to respond to it. Some academics have devoted official pages other than their pages to provide academic advising to their students, and file reports and required documentation to their superiors and administrative.

This study was conducted at the community college in Imam Abdulrahman Bin Faisal University trying to capture the perception of the first- and second-year students of online academic advising services in the college. The academic advising in Imam Abdulrahman Bin Faisal University usually follows a face-to-face approach; in which each academic advisor must meet the students twice each semester and must be available in the first week of the semester to help to direct students in their registration. The academic advising process in the college involves two meetings between the academic advisors and students each semester. Each semester, students are required to fill a form about the courses they want to register after the discussion with their academic advisors. The academic advisor then summarizes the required courses in another form. At the end of the semester, each academic advisor is required $t$ submit the academic advising file to the coordinator of the unit with the required files. The file must contain meetings reports, attendance sheet signed by the students, a summary of the required courses for the next semester filled by the academic advisor. Students are encouraged to evaluate their academic advisors each semester using an online survey. The results of the survey are forwarded to the coordinator of the academic advising unit on each campus. The coordinator of the academic advising unit is required to submit a plan that entails recommendations and improvements of each point.

All educational institutions are forced to close and send their students home to start online teaching and create a possible success for all students. This new experiment in online teaching will accelerate the change in the educational system. Imam Abdulrahman Bin Faisal University has adopted new online services for academic advising to meet student needs in light of the new situation. The main contribution of this study falls within clustering students to groups based on their attitudes toward the academic advising unit according to new online services provided by the unit. The analysis of the collected data can shed light on the strength and weak points of each cluster to develop the appropriate strategy. 
The remaining of this research is structured into four sections; data collection and data analysis are presented in Section 2 . In Section 3, research findings are elaborated. Section 5 provides the conclusion of the study.

\section{Data Collection}

At the beginning of the study, we interviewed the coordinator of the academic advising unit in order to inspect the most important issues to focus on in this study. This study was performed at the Community College of two campuses in the Imam Abdulrahman Bin Faisal University. Female students who are in their first and second year of the diploma of computer or business programs were invited to fill the questionnaire for two weeks at the beginning of March in 2020. Thus, each student responded once to the questionnaire. Students were encouraged to fill the questionnaire by their academic advisors and by the departments. The link of the questionnaire was uploaded to students on the blackboard system with a notification for the students. Table 1 presents the questions of the survey.

Table 1

Items of the Scale

\begin{tabular}{|c|c|c|}
\hline Construct & Item & \\
\hline \multirow{7}{*}{$\begin{array}{l}\text { Academic plan and } \\
\text { course registration }\end{array}$} & 1. $\mathrm{AP} 1$ & Reviews my academic record before choosing the courses. \\
\hline & 2. $\mathrm{AP} 2$ & Helps me choose courses. \\
\hline & AP3 & Provided me with information about my courses and their requirements \\
\hline & AP4 & I contact my academic advisor online before processing the deletion or addition of courses. \\
\hline & AP5 & I am fully aware of the study plan and graduation requirements \\
\hline & AP6 & Helps me understanding why required courses are important in this sequence. \\
\hline & AP7 & Has assisted me in developing a long-term education plan. \\
\hline \multirow[t]{4}{*}{ Availability } & AV1 & I can easily contact my advisor when needed. \\
\hline & 9. $\quad$ AV2 & Interacts through electronic communication. \\
\hline & 10. AV3 & Specifies the academic advising hours through online portals. \\
\hline & 11. AV4 & Always available online during his academic advising hours. \\
\hline \multirow{4}{*}{$\begin{array}{l}\text { Relationship with } \\
\text { the academic } \\
\text { advisor }\end{array}$} & 12. REL1 & Answers my questions effectively. \\
\hline & 13. REL2 & My academic advisor is ready for advising me. \\
\hline & 14. REL3 & Academic advising is a shared responsibility. \\
\hline & 15. REL4 & I have a good relationship with my academic advisor. \\
\hline \multirow{3}{*}{$\begin{array}{l}\text { Encouraging the } \\
\text { student }\end{array}$} & 16. ENC1 & The way my academic advisor treats me makes me feel comfortable. \\
\hline & 17. $\mathrm{ENC} 2$ & Encouraged me to come to attend online meetings. \\
\hline & 18. ENC3 & Encouraged me to excel in my studies. \\
\hline \multirow{3}{*}{$\begin{array}{l}\text { Student academic } \\
\text { level follow-up }\end{array}$} & 19. FOLL1 & Helps me develop an action plan. \\
\hline & 20. FOLL2 & Aware of my academic weakness and offers me the proper guidance \\
\hline & 21. FOLL3 & Notifies me to make sure, no discrepancies in the final tests schedule \\
\hline \multirow{5}{*}{$\begin{array}{l}\text { Rules, services and } \\
\text { regulations }\end{array}$} & 22. RUL1 & Provided me with information on IAU regulations \\
\hline & 23. RUL2 & I can utilize the online services offered through the IAU website \\
\hline & 24. RUL3 & $\begin{array}{l}\text { Refers me to other campus online resources (Academic Achievement Center, Career Services, tutoring, } \\
\text { personal counseling. }\end{array}$ \\
\hline & 25. RUL4 & Provided me with information on IAU bylaws. \\
\hline & 26. RUL5 & I can utilize the online services offered through IAU departments. \\
\hline
\end{tabular}

\section{Data Analysis}

The analysis of the data entails four main parts, which are: (1) demographic data analysis, (2) principal component analysis with Varimax rotation, (3) cluster analysis, and (4) a comparison between segmented clusters in terms of campus, academic advisor communication language, and department.

\subsection{Demographic Information Analysis}

The total number of students who participated in the survey is 738. Students who participated in the survey have finished their property year and enrolled in one of the programs which are provided by the college. Students can choose either a computer program or a business program. As Table 2 presents 49.9 of the students are enrolled in the business program, while 50.1 of the students are in the computer program. Each program has three main tracks. In the business program, after passing the general courses in the first year of the program, students can apply to proceed in one of the offered tracks. In the computer program, students can choose their tracks from the first year. However, in this survey, we didn't include students from the property year as they have different management and policies regarding academic advising. Students are advised by either Arab advisors or non-Arab advisors. Academic advising coordinators have indicated that students usually prefer to communicate with Arab-academic advisors. Some of the non-Arab academic advisors direct their students to the unit as they can't understand student needs. However, each faculty member has his academic advisory tasks. Each academic advisor is assigned to 20-30 students whom she must direct and follow up with them during the academic year. 
Table 2

Demographic Information

\begin{tabular}{llll}
\hline & Item & Number & Percentage \\
\hline Year & First Year & 335 & 45.4 \\
& Second Year & 403 & 54.6 \\
\hline Track & Computer Science & 121 & 16.4 \\
& Information System & 129 & 17.5 \\
& InformationTechnology & 120 & 16.3 \\
& Finance & 89 & 12.1 \\
& Insurance & 156 & 21.1 \\
& Supply Chain & 123 & 16.7 \\
\hline Campus & Qatif & 302 & \\
& Dammam & 436 & \\
\hline Department & Business & 368 & \\
& Computer & 370 & \\
\hline Academic Advisor & Non-Arabic & 324 & \\
Language & Arabic & 418 & \\
\hline
\end{tabular}

\subsection{The Segmentation Approach}

The patterns between constructs can be located by applying principle component analysis to the primary questions of the survey. Following that, a set of questions with correlations between them can be classified and labeled under a specific dimension. Constructs' dimensions can clarify the relations between the questions in the same dimension. Principle component analysis is used primarily to minimize labeling each set of correlated questions under a specific factor. Hence, a Varimax rotation method was applied and only questions with loadings above 0.4 were kept for further analysis. The result of the principal component analysis is presented in Table 3.

Table 3

The Result of Principle Component Analysis

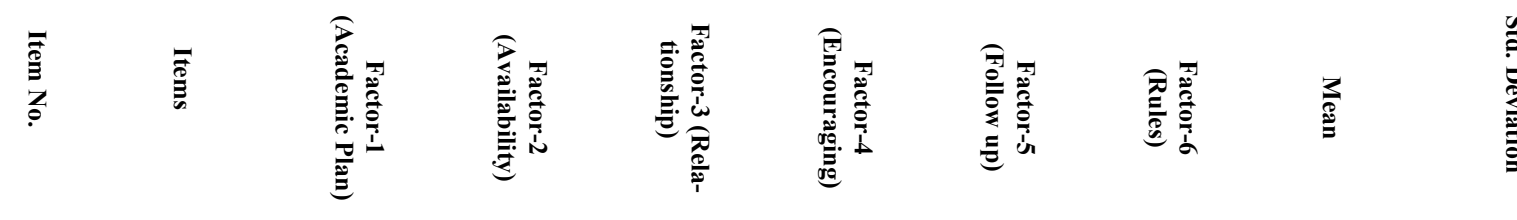

\begin{tabular}{|c|c|c|c|c|c|c|c|c|c|}
\hline 1. & AP1 & 0.667 & & & & & & 4.1816 & 0.88992 \\
\hline 2. & AP2 & 0.818 & & & & & & 4.2127 & 0.87603 \\
\hline 3. & AP3 & 0.824 & & & & & & 4.2114 & 0.90155 \\
\hline 4. & AP4 & 0.833 & & & & & & 4.2033 & 0.87597 \\
\hline 5. & AP5 & 0.702 & & & & & & 4.0136 & 0.94622 \\
\hline 6. & AP6 & 0.780 & & & & & & 4.1179 & 0.89226 \\
\hline 7. & AP7 & 0.726 & & & & & & 4.1152 & 0.99606 \\
\hline 8. & AV1 & & & & 0.782 & & & 3.8591 & 0.92555 \\
\hline 9. & AV2 & & & & 0.768 & & & 3.9092 & 0.91045 \\
\hline 10. & AV3 & & & & 0.801 & & & 3.7182 & 1.02438 \\
\hline 11. & AV4 & & & & 0.817 & & & 3.7425 & 0.97394 \\
\hline 12. & ENC1 & & & & & 0.850 & & 4.1938 & 0.78770 \\
\hline 13. & ENC2 & & & & & 0.865 & & 4.1436 & 0.77685 \\
\hline 14. & ENC3 & & & & & 0.801 & & 4.2642 & 0.77221 \\
\hline 15. & RUL1 & & & 0.601 & & & & 3.9404 & 0.99071 \\
\hline 16. & RUL2 & & & 0.684 & & & & 4.0339 & 0.94643 \\
\hline 17. & RUL3 & & & 0.799 & & & & 4.0081 & 0.92892 \\
\hline 18. & RUL4 & & & 0.794 & & & & 3.8862 & 0.95803 \\
\hline 19. & RUL5 & & & 0.711 & & & & 4.0691 & 0.92418 \\
\hline 20. & REL1 & & 0.841 & & & & & 4.1314 & 0.90697 \\
\hline 21. & REL2 & & 0.841 & & & & & 4.0664 & 0.91996 \\
\hline 22. & REL3 & & 0.817 & & & & & 4.1084 & 0.88966 \\
\hline 23. & REL4 & & 0.828 & & & & & 4.0705 & 0.90103 \\
\hline 24. & FOLL1 & & & & & & 0.730 & 4.0027 & 0.96196 \\
\hline 25. & FOLL2 & & & & & & 0.923 & 4.0799 & 0.95509 \\
\hline 26. & FOLL3 & & & & & & 0.877 & 4.1192 & 0.90341 \\
\hline \multicolumn{2}{|c|}{ Eigenvalue } & 7.724 & 3.622 & 2.168 & 2.073 & 1.397 & 1.273 & & \\
\hline \multicolumn{2}{|c|}{ Variance explained } & 29.709 & 43.641 & 51.980 & 59.951 & 65.324 & 70.220 & & \\
\hline
\end{tabular}

The principle component test generated six main factors as presented in Table 3 . The main factors produced by the principal component test are (1) academic plan and course registration with seven items, (2) availability with four items, (3) relationship 
with an academic advisor with four items, (4) encouraging the student with three items, (5) student academic level follow-up with three items, (6) rules, services and regulations with five items. Meyer-Olkin measure confirms the suitability of the factor analysis test and implies the appropriateness of the test with values above 0.5. Bartlett's test of sphericity is applied to test the level of correlation between variables in the collected data. Meyer-Olkin measure of sampling adequacy result is quite high (0.867) and Bartlett's test of sphericity is significant. Twenty-six variables have mean values above 3.7 and standard deviations' scores above 0.77 . To find patterns between students, rather than between factors, we applied cluster analysis through a two-step cluster method as recommended by (Punj \& Stewart, 1983) study. In the first step, the Ward's minimum variance method was performed to determine the suitable number of groups. The determination of the number of clusters was based on the test of the agglomeration coefficients from the Ward. The number of clusters was determined upon specifying a demarcated change in the agglomeration coefficients' values. Hence, based on the result of the hierarchical clustering method, we find that the suitable number of clusters is 3 . The second step includes the performance of the $k$-means clustering method to group students based on the number of groups obtained from hierarchical cluster analysis. A summary of the cluster analysis result is presented in Table 4.

Table 4

Summary of Cluster Analysis

\begin{tabular}{lcccc}
\hline Criteria & $\mathbf{1}^{\text {th }}$ cluster $(\mathbf{n = 1 7 2})$ & $\mathbf{2}^{\text {th }}$ cluster $(\mathbf{n = 1 6 6 )}$ & $\mathbf{3}^{\text {th }}$ cluster $(\mathbf{n = 4 0 0 )}$ & Sig. \\
\hline AP & 3.28 & 4.29 & 4.47 & 0.000 \\
AV & 3.13 & 3.63 & 4.17 & 0.000 \\
ENC & 3.90 & 3.90 & 4.45 & 150.937 \\
RUL & 3.23 & 3.80 & 4.39 & 73.475 \\
REL & 4.04 & 3.29 & 4.45 & 234.011 \\
FOLL & 4.33 & 3.07 & 4.37 & 0.000 \\
\hline
\end{tabular}

\subsection{Comparison between Segmented Clusters}

To analyze the differences between clusters in terms of (1) mean scores of the factors generated from the factor analysis, (2) campus, (3) year, (4) department, (5) track, (6) academic advisor language, and the resulted cluster membership, we applied an ANOVA test with Tukey's posthoc multiple comparisons. The outcomes presented significant differences between the resulted clusters in terms of the mean scores of the factors generated from the factor analysis, year, department, academic advisor language, and track (see Table 5). However, in terms of the campus, the result did not provide proof of significant differences between clusters. Table 5 presents the comparison between the clusters using the One-Way ANOVA test.

\section{Findings}

Cluster 1 has the highest score for: "Student Academic Level Follow Up" and "Students Relations with their Academic Advisors". Hence, students in this cluster have a good relationship with their academic advisors. Students in this cluster have a positive attitude towards the care provided from their advisors as they are interested in their academic level and as they try to follow up with them by understanding their academic situations and helping them effectively. This group mainly represents second-year students (75.6\%). Most of the students in this group are enrolled in the computing department (79.7\%). In cluster 1 , most of the students $(90.1 \%)$ have non-Arabic academic advisors.

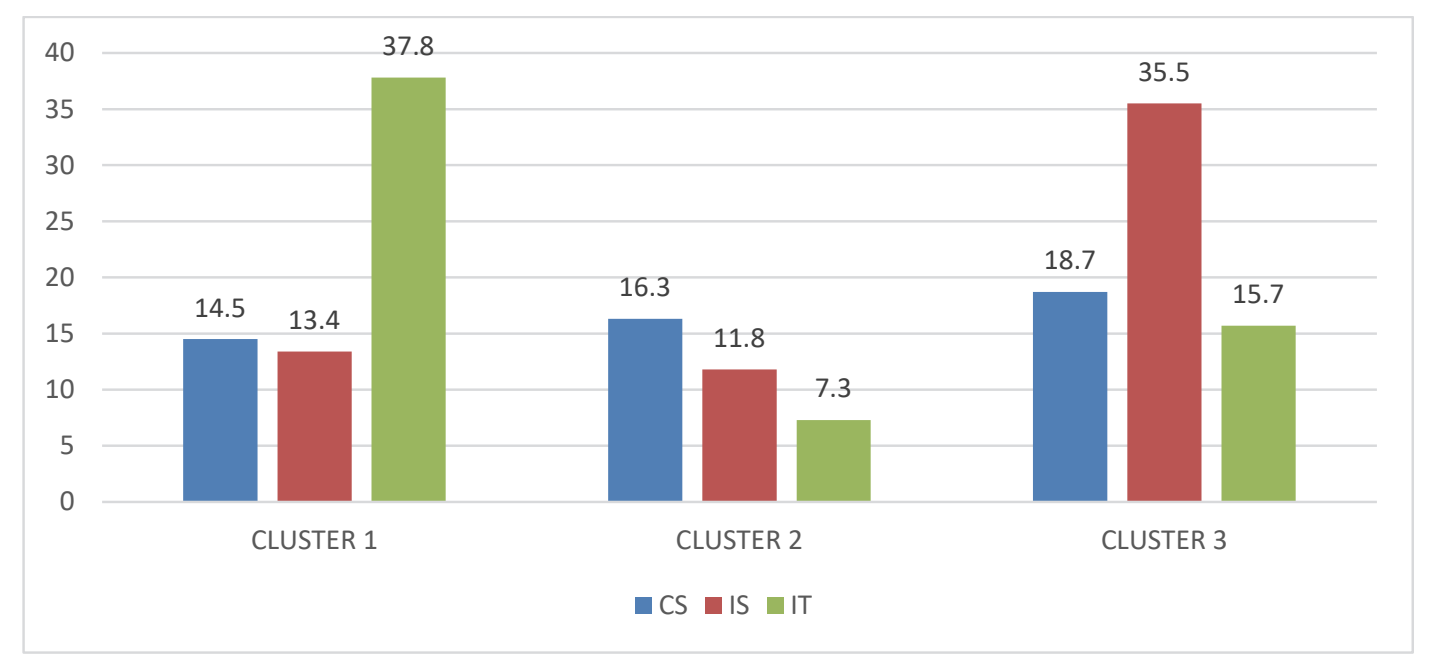

Fig. 1. Computing Department Tracks Among the Three Clusters 


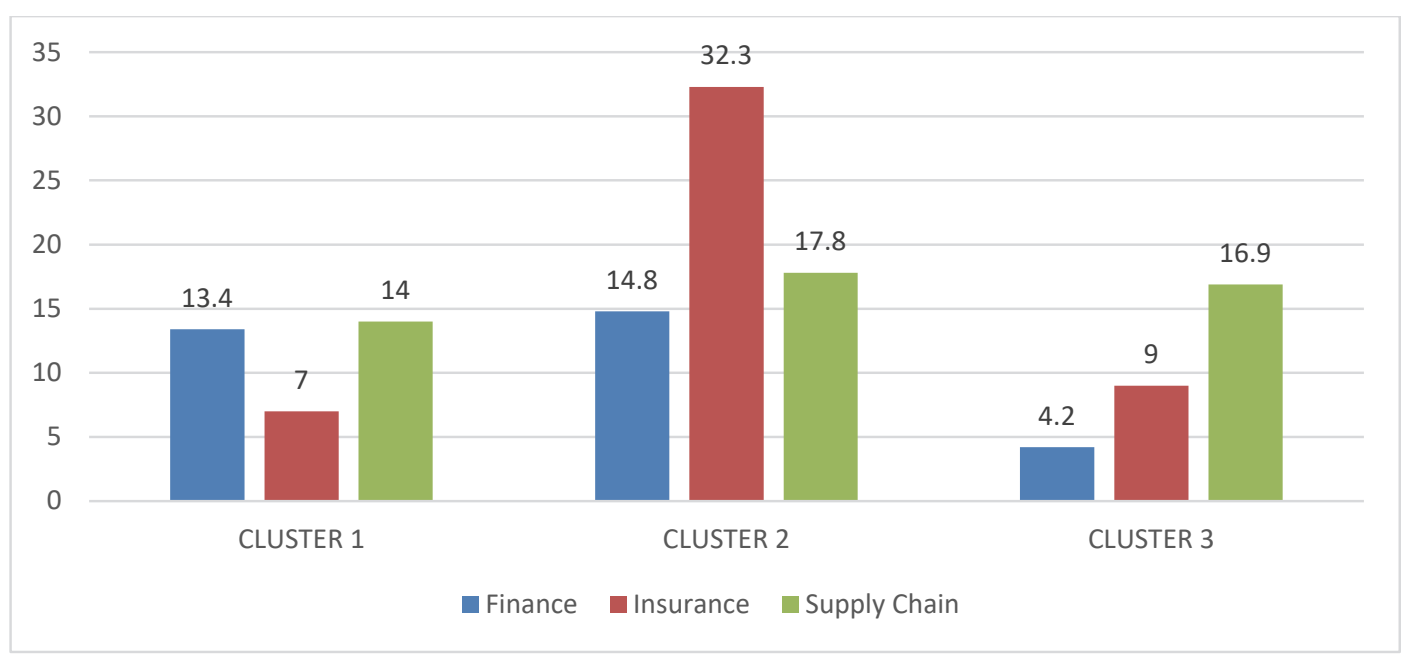

Fig. 2. Business Department Tracks Among the Three Clusters

As Fig. 1 and Fig.2 show the majority of students in this cluster are enrolled in the information technology track in the computer department, and in the supply chain track in the business department. Cluster 2 has the highest score for "Academic Plan and Registration". Hence, students in this cluster have a good feeling about the services provided by the academic advising unit during the registration period. Most of the students in this cluster represent first-year students (81.3\%). Most of the students in this group are enrolled in the business department $(81.3 \%)$. However, student attitude towards the academic advising services in this cluster has achieved the lowest values among other clusters. This can be explained regarding the lack of communication between first-year students and their academic advisors in general. Students are less aware of university regulations than second-year students. The relationship between the student and the academic advisor can be enhanced over time.

Table 5

Results of One-Way ANOVA Test

\begin{tabular}{|c|c|c|c|c|c|c|}
\hline & & Sum of Squares & $\mathrm{df}$ & Mean Square & $\mathrm{F}$ & Sig. \\
\hline \multirow[t]{3}{*}{ Track } & Between Groups & 108.105 & 2 & 54.053 & 18.836 & .000 \\
\hline & Within Groups & 2109.175 & 735 & 2.870 & & \\
\hline & Total & 2217.280 & 737 & & & \\
\hline \multirow[t]{3}{*}{ Year } & Between Groups & 30.389 & 2 & 15.194 & 73.210 & .000 \\
\hline & Within Groups & 152.545 & 735 & .208 & & \\
\hline & Total & 182.934 & 737 & & & \\
\hline \multirow[t]{3}{*}{ Campus } & Between Groups & 1.427 & 2 & .714 & 2.963 & .052 \\
\hline & Within Groups & 176.990 & 735 & .241 & & \\
\hline & Total & 178.417 & 737 & & & \\
\hline \multirow[t]{3}{*}{ Department } & Between Groups & 31.410 & 2 & 15.705 & 75.402 & .000 \\
\hline & Within Groups & 153.089 & 735 & .208 & & \\
\hline & Total & 184.499 & 737 & & & \\
\hline \multirow[t]{3}{*}{ Academic Advisor } & Between Groups & 138.772 & 2 & 69.386 & 1200.697 & 0.000 \\
\hline & Within Groups & 42.474 & 735 & 0.058 & & \\
\hline & Total & 181.247 & 737 & & & \\
\hline \multirow[t]{3}{*}{ AP } & Between Groups & 173.692 & 2 & 86.846 & 306.529 & .000 \\
\hline & Within Groups & 208.241 & 735 & .283 & & \\
\hline & Total & 381.933 & 737 & & & \\
\hline \multirow[t]{3}{*}{$\mathrm{AV}$} & Between Groups & 136.877 & 2 & 68.438 & 150.937 & .000 \\
\hline & Within Groups & 333.267 & 735 & .453 & & \\
\hline & Total & 470.144 & 737 & & & \\
\hline \multirow[t]{3}{*}{ ENC } & Between Groups & 55.445 & 2 & 27.722 & 73.475 & .000 \\
\hline & Within Groups & 277.320 & 735 & .377 & & \\
\hline & Total & 332.764 & 737 & & & \\
\hline \multirow[t]{3}{*}{ RUL } & Between Groups & 166.806 & 2 & 83.403 & 234.011 & .000 \\
\hline & Within Groups & 261.959 & 735 & .356 & & \\
\hline & Total & 428.765 & 737 & & & \\
\hline \multirow[t]{3}{*}{ REL } & Between Groups & 160.857 & 2 & 80.428 & 197.726 & .000 \\
\hline & Within Groups & 298.973 & 735 & .407 & & \\
\hline & Total & 459.830 & 737 & & & \\
\hline \multirow[t]{3}{*}{ FOLL } & Between Groups & 213.898 & 2 & 106.949 & 269.632 & .000 \\
\hline & Within Groups & 291.537 & 735 & .397 & & \\
\hline & Total & 505.435 & 737 & & & \\
\hline
\end{tabular}


In cluster 2, most of the students (90. \%) have non-Arabic academic advisors. Most of the students in this cluster are enrolled in the computer science track in the computer department, and in the insurance track in the business department. Cluster 3 has high scores for all survey factors. Hence, we labeled this cluster as a satisfied-students cluster. Students in this cluster have positive feelings about all the services provided by academic advising. This group mainly represents second-year students $(60.5 \%)$. Students in this cluster are divided between the two departments equally. This cluster has achieved the highest values among other clusters regarding the positive attitude towards academic advising services. In cluster 3, most of the students $(96.5 \%)$ have Arabic academic advisors. Most of the students in this cluster are enrolled in the information system track in the computer department, and in the supply chain track in the business department.

\section{Conclusion}

Segmentation is used in user-based studies, trying to understand users' usage habits, average income, educational level, etc. The segmentation process can provide decision-makers with insights about the targeted audience and enable them to plan the required strategies effectively (Chang, 2006; Chen, Huang, Shu, \& Wang, 2013; Susilo, 2016; Tkaczynski, Rundle-thiele, \& Prebensen, 2015). However, adopting the segmentation analysis trying to understand student attitudes can provide significant implications in educational research. The segmentation process can be achieved through exploratory techniques, in which the researcher tries to find patterns with common sense in the collected data. Hence, the segmentation process of the collected data is not a straight forward task (Ansory \& Safira, 2018; Denizci Guillet, Guo, \& Law, 2015; Grisé \& El-geneidy, 2018; Sari, Setiaboedi, \& Management, 2015). It requires a critical analysis of different options of clusters to provide the justified grouping of individuals.

In this research, a three-clusters solution and six factors have resulted from the analysis of the data. Following the new instructions in response to COVID-19 spread in the world, academic advisors moved to online services to support their students. Academic advisors conduct their sessions using different tools that are provided from the university website. So, instead of face to face meetings between the advisors and the students, they have conducted their meeting online. The main approach to achieve the tasks is the online video meeting through computers, tablets, and smartphones, which "may involve one to one interaction or one to many interactions". The result of the analysis gave us important indications about academic advising in the university during the shift the university performed towards online academic advising services. Other electronic services provided by the university allow the academic advisor to review advisees' applications and transfer students who need help to the counseling unit or to the department based on their situations. Cluster 3 has the highest mean value, which is equal to or higher than 4 in all factors. Cluster 2 has mean values that are less than 4 in all factors. However, Cluster 3 constitutes the hugest portion of the sample. This can indicate that most students in the sample have a positive attitude towards academic advising online services on both campuses. The distribution of academic advisors over the three clusters raises an important issue regarding the communication language between the academic advisors and the students. Students in cluster 3 (which we labeled as the satisfied cluster) has $96.5 \%$ of Arab academic advisors. This result indicates an important argument regarding the impact of the communication language between the academic advisor and the student on their attitude towards the services provided to them. Even though students communicate with non-Arab in the traditional lectures, the academic expressions required in the educational process might differ from expressions required to communicate with their academic advisors. This can be confirmed as the students show a negative attitude towards non-Arab academic advisors regarding language constraints. Although the English language has become a leading language in global interaction (Llamas \& Escalante, 2001), and the tremendous pressure of universities among their faculty members to teach only in the English language, still; students face difficulties in communicating with their academic advisors in individual conversations. Students need to enhance their communication skills in the English language (Sun, 2020). This can be achieved by implementing positive interaction methods (Al-Ajmi \& Aljazzaf, 2020; Wahyudi, 2020). Most of the non-English college students consider English as a language for studying courses only (Heping, Jinchuan, Rongping, \& Zhenli, 2013). Despite the long time they spend studying their courses in the English language, their aim is limited primarily to passing their courses.

Looking at the practical implication of this study, this research can highlight some important indications for decision-makers in the university. The differences that have been highlighted between different clusters of students in this research must be taken into consideration during the planning of academic advising strategies. One of the points that must be considered is that the first-year students should be instructed carefully about the services provided by the academic advising unit. More meetings must be conducted to increase their awareness of the provided services. Based on the results of the evaluation, the coordinator in each campus nominates the best academic advisor to be honored by the Dean of the college. Besides, following the results of the survey, the coordinator of the academic advising unit in each campus is required to provide recommendations for improvement based on the weak points presented in the survey results. Hence, we summarized the recommendations provided by the coordinators as follows:

- Encourage academic advisors to build a strong relationship with the students.

- Encourage the academic advisors to provide the students with IAU regulations and bylaws

- Clarify the information about courses and their requirements for academic advisors.

- Clarify the information about graduation requirements for academic advisors. 


\section{References}

Al-Ajmi, N. H., \& Aljazzaf, Z. (2020). Factors Influencing the Use of Multimedia Technologies in Teaching English Language in Kuwait. International Journal of Emerging Technologies in Learning (IJET), 15(05), 212.

Al-Ansari, A., El Tantawi, M., AbdelSalam, M., \& Al-Harbi, F. (2015). Academic advising and student support: Help-seeking behaviors among Saudi dental undergraduate students. Saudi Dental Journal, 27(2), 57-62.

Ansory, S. M., \& Safira, A. (2018). Age segmentation for predicting behavioural intention of using railway services in Indonesia. Asian Journal of Business and Accounting, 11(1), 229-264. https://doi.org/10.22452/ajba.vol1 1no1.8

Chan, Z. C. Y. (2016). A qualitative study of freshmen's and academic advisors' perspectives on academic advising in nursing. Nurse Education in Practice, 18, 23-29. https://doi.org/10.1016/j.nepr.2016.02.010

Chan, Z. C. Y., Chan, H. Y., Chow, H. C. J., Choy, S. N., Ng, K. Y., Wong, K. Y., \& Yu, P. K. (2019). Academic advising in undergraduate education: A systematic review. Nurse Education Today, 75(December 2018), 58-74.

Chang, J. (2006). Segmenting tourists to aboriginal cultural festivals: An example in the Rukai tribal area, Taiwan. Tourism Management, 27(6), 1224-1234. https://doi.org/10.1016/j.tourman.2005.05.019

Chen, N. H., Huang, S. C. T., Shu, S. T., \& Wang, T. S. (2013). Market segmentation, service quality, and overall satisfaction: Self-organizing map and structural equation modeling methods. Quality and Quantity, 47(2), 969-987.

Denizci Guillet, B., Guo, Y., \& Law, R. (2015). Segmenting hotel customers based on rate fences through conjoint and cluster analysis. Journal of Travel and Tourism Marketing, 32(7), 835-851. https://doi.org/10.1080/10548408.2015.1063825

Diederiks, Y., \& Figueroa, I. (2016). The usability of academic advising forms. Proceedings of the Human Factors and Ergonomics Society, 1383-1387. https://doi.org/10.1177/1541931213601319

Gaines, T. (2014). Technology and Academic Advising: Student Usage and Preferences. NACADA Journal, 34(1), $43-49$.

Grisé, E., \& El-geneidy, A. (2018). Where is the happy transit rider? Evaluating satisfaction with regional rail service using a spatial segmentation approach. Transportation Research Part A: Policy and Practice, 114(November 2017), 84-96.

Hatch, D. K., \& Garcia, C. E. (2017). Academic advising and the persistence intentions of community college students in their first weeks in college. Review of Higher Education (Vol. 40). https://doi.org/10.1353/rhe.2017.0012

He, Y., \& Hutson, B. (2016). Appreciative assessment in academic advising. Review of Higher Education, 39(2), $213-240$.

Heping, W., Jinchuan, Z., Rongping, F., \& Zhenli, S. (2013). Teaching Non-English-Majored College Students Listening and Speaking Through Multimedia and Network. International Journal of Education and Management Engineering, 3(1), 4448. https://doi.org/10.5815/ijeme.2013.01.08

Iatrellis, O., Kameas, A., \& Fitsilis, P. (2017). Academic Advising Systems: A Systematic Literature Review of Empirical Evidence. Education Sciences, 7(4), 90. https://doi.org/10.3390/educsci7040090

Jaradat, M. S., \& Mustafa, M. B. (2017). Academic advising and maintaining major: Is there a relation? Social Sciences, 6(4). Lawton, J. (2018). Academic Advising as a Catalyst for Equity. New Directions for Higher Education, $2018(184), 33-43$.

Llamas, E., \& Escalante, V. W. (2001). Predicting results of morphology teaching in non-English-speaking countries [3]. Anatomical Record. https://doi.org/10.1002/ar.1148

Powers, K. L., Carlstrom, A. H., \& Hughey, K. F. (2014). Academic Advising Assessment Practices: Results of a National Study. NACADA Journal, 34(1), 64-77. https://doi.org/10.12930/nacada-13-003

Punj, G., \& Stewart, D. W. (1983). Cluster Analysis in Marketing Research: Review and Suggestions for Application. Journal of Marketing Research, 20(2), 134. https://doi.org/10.2307/3151680

Sari, H., Setiaboedi, A. P., \& Management, I. E. (2015). Segmentation of Online Buyers and Its Implication in Determining Marketing Strategies, 34-39.

Sun, H. (2020). The Learning Method of Peer Review in College English Writing Course. International Journal of Emerging Technologies in Learning (IJET), 15(05), 156. https://doi.org/10.3991/ijet.v15i05.13775

Susilo, W. H. (2016). An Impact of Behavioral Segmentation to Increase Consumer Loyalty: Empirical Study in Higher Education of Postgraduate Institutions at Jakarta. Procedia - Social and Behavioral Sciences, 229, $183-195$. https://doi.org/10.1016/j.sbspro.2016.07.128

Tkaczynski, A., Rundle-thiele, S. R., \& Prebensen, N. K. (2015). Segmenting Potential Nature-Based Tourists Based on Temporal Factors : The Case of Norway, 3. https://doi.org/10.1177/0047287513514296

Wahyudi, W. (2020). The Effectiveness of Sharing Blended Project Based Learning (SBPBL) Model Implementation in Operating System Course. International Journal of Emerging Technologies in Learning (IJET), 15(05), 202. https://doi.org/10.3991/ijet.v15i05.11266

Zarges, K. M., Adams, T. A., Higgins, E. M., \& Muhovich, N. (2018). Assessing the Impact of Academic Advising: Current Issues and Future Trends. New Directions for Higher Education, 2018(184), 47-57. https://doi.org/10.1002/he.20302

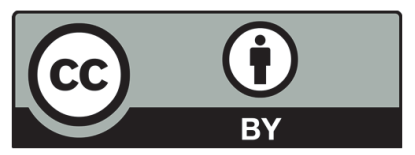

(C) 2021 by the authors; licensee Growing Science, Canada. This is an open access article distributed under the terms and conditions of the Creative Commons Attribution (CC-BY) license (http://creativecommons.org/licenses/by/4.0/). 